\title{
Mikobakterioza płuc. Rzadka choroba czy narastający problem epidemiologiczny?
}

\author{
Non-tuberculous mycobacterial lung disease. Rare entity or emerging epidemiological \\ problem?
}

Praca nie była finansowana

Prątki niegruźlicze (NTM, non-tuberculous mycobacteria) stanowią dużą grupę drobnoustrojów, obejmującą około 140 gatunków. Są bardzo rozpowszechnione w środowisku, w glebie i w wodzie, a w szczególności na jej powierzchni. Mogą bytować w amebach i pierwotniakach [1]. Tylko część NTM, według różnych danych 20-40 gatunków, została opisana w związku z wywołaniem choroby u ludzi [2-4].

Do zakażenia dochodzi w wyniku kontaktu z bakteriami w środowisku. Dotychczas uważano, że nie występuje zakażenie odzwierzęce ani między ludźmi, jednak opisane w ostatnich latach epizody wskazują na taką możliwość. Transmisję Mycobacterium abscessus subspecies massiliense między ludźmi stwierdzono w dwóch różnych ośrodkach dla chorych na mukowiscydozę [3, 5-7].

Prątki niegruźlicze są stosunkowo mało patogenne. Mogą więc wywoływać chorobę, kolonizować drogi oddechowe bądź tylko stanowić zanieczyszczenie. Dlatego dla rozpoznania choroby konieczne jest spełnienie kryteriów klinicznych, radiologicznych i mikrobiologicznych opracowanych przez Amerykańskie Towarzystwo Chorób Klatki Piersiowej (ATS, American Thoracic Society) i Amerykańskie Towarzystwo Chorób Zakaźnych (IDSA, Infectious Diseases Society of America) [2]. Dodatkowym argumentem przema- wiającym za rozpoznaniem choroby jest gatunek wyhodowanych prątków - najsilniej wskazuje na chorobę wyhodowanie najbardziej patogennych: Mycobacterium kansasii, Mycobacterium malmoense i Mycobacterium szulgai. Rzadko występują choroby wywołane Mycobacterium gordonae, Mycobacterium chelonae i Mycobacterium simiae. Mycobacterium avium intracellulare, Mycobacterium xenopii i Mycobacterium abscessus stanowią grupę pośrednią $[8,9]$.

Choroba wywołana przez NTM najczęściej dotyczy płuc, rzadziej węzłów chłonnych, a najrzadziej innych narządów [10,11]. Postać rozsiana występuje wyłącznie w przypadkach ciężkich niedoborów immunologicznych bądź to o charakterze wrodzonym dotyczącym osi IFN- $\gamma /$ IL-12 [10], bądź też nabytym (zakażenie HIV, leczenie preparatami anty-TNF, stan po przeszczepieniu narządów) [9, 12].

Mikobakterioza płuc przebiega pod 3 różnymi postaciami klinicznymi $[3,9,10]$. Pierwsza z nich ma charakter bardzo zbliżony do gruźlicy i charakteryzuje się występowaniem jam, zwykle w górnych partiach płuc. Ta postać jest często mylnie rozpoznawana jako gruźlica przed dokonaniem identyfikacji prątków. Druga postać mikobakteriozy (najbardziej charakterystyczna dla szczupłych kobiet w okresie menopauzy) charakteryzuje się występowaniem rozstrzeni

Adres do korespondencji: prof. dr hab.n. med. Ewa Rowińska-Zakrzewska, e-mail: monika.szturmowicz@gmail.com

DOI: 10.5603/PiAP.2014.0064

Praca wpłynęła do Redakcji: 9.09 .2014 r.

Copyright (C) 2014 PTChP

ISSN 0867-7077 
i guzków, zwykle zlokalizowanych w obrębie płata środkowego i języczka. Trzecia postać, o objawach zbliżonych do alergicznego zapalenia pęcherzyków płucnych, polega na występowaniu zmian rozsianych i duszności po narażeniu na ekspozycję prątkami znajdującymi się w aerozolach wodnych w saunie, podczas kąpieli pod prysznicem lub w pomieszczeniu klimatyzowanym. Jest to postać najłagodniejsza, która zwykle ustępuje po ustaniu ekspozycji i na ogół nie wymaga leczenia, a jeżeli jest ono konieczne, to może trwać znacznie krócej niż leczenie innych postaci mikobakterioz [3, 8, 9].

Występowanie mikobakterioz płuc jest częściowo uwarunkowane genetycznie, w innych przypadkach wikła różne choroby układu oddechowego. Najlepiej poznaną genetyczną przyczyną występowania mikobakteriozy płuc jest mukowiscydoza. Autosomalne recesywne mutacje genu CFTR (cystic fibrosis transmembrane conductance regulator), które odpowiadają za rozwój tej choroby, powodują zaburzenia w transporcie sodu i chloru przez powierzchnię nabłonków. Przyczynia się to między innymi do zmiany charakteru wydzieliny oskrzelowej, trudności w oczyszczaniu dróg oddechowych i powstawania rozstrzeni [13]. U części chorych z mikobakteriozą płuc o pozornie samoistnym rozwoju wykrywa się inne typy mutacji CFTR $[14,15]$.

Innymi wrodzonymi przyczynami powstawania mikobakteriozy płuc mogą być wrodzone defekty w strukturze i funkcji rzęsek oraz nieprawidłowa odpowiedź na bodźce związana ze zmianami w tak zwanych „receptorach typu toll”, czyli rozpoznających określone wzory (w tym określonych bakterii). Stwierdzono również zwiększoną wrażliwość na zachorowanie na mikobakteriozę płuc w pewnych polimorfizmach genu NRAMP1 (natural-resistance-associated macrophage protein 1) [16-18].

Pozornie samoistna postać choroby u kobiet w okresie menopauzy (nazywana dawniej zespołem lady Windermere) często wiąże się $\mathrm{z}$ występowaniem rodzinnym. W rozwoju tej choroby mogą odgrywać rolę: obniżone stężenie estrogenów w czasie menopauzy oraz zmieniona ekspresja leptyny i adiponektyny u kobiet o szczupłej budowie ciała. Wydaje się ponadto, że obserwowane w tych przypadkach zmiany struktury kostnej klatki piersiowej mogą również mieć tło genetyczne [11, 15].

Najczęstszą przyczyną zakażenia NTM są przebyte lub przewlekłe choroby płuc [11, 19]. Według badań Andrejak i wsp. przewlekłe choroby płuc wiążą się z 16,5-krotnym wzrostem ryzyka zachorowania na mikobakteriozę. W badaniach populacyjnych przeprowadzonych w Danii autorzy ci stwierdzili, że dla POChP ryzyko to było 15,7 raza wyższe, dla astmy $5,2-11,6$ raza, dla pylicy 9,8 raza, dla rozstrzeni oskrzeli 187,5 raza i dla przebytej gruźlicy 178,3 raza [20]. We wszystkich tych grupach ryzyko znamiennie się zwiększało, gdy chorzy byli leczeni kortykosteroidami i zależało od dawki leku [21].

Częstość zachorowań na mikobakteriozę płuc rośnie. W Stanach Zjednoczonych jest ona obecnie wyższa niż zachorowalność na gruźlicę [22-25]. Ponadto z uwagi na trudności związane $\mathrm{z}$ leczeniem tej choroby rokowanie jest złe $-40 \%$ chorych umiera w ciągu 5 lat [26].

W aktualnym numerze „Pneumonologii i Alergologii Polskiej” znajdują się 2 prace na temat mikobakteriozy płuc. Jedna dotyczy chorych z mukowiscydozą i dobrze obrazuje trudności rozpoznawcze i ryzyko, które wiąże się z zakażeniem NTM w tej chorobie [27]. Druga praca ma niezwykle nowatorski charakter. Wykazuje bowiem po raz pierwszy w literaturze światowej, że czynnikiem ryzyka zachorowania na mukowiscydozę mogą być zaburzenia przepływu krwi w płucach obserwowane w nadciśnieniu płucnym [28]. Biorąc pod uwagę, że przypadki nadciśnienia płucnego, zarówno samoistnego, jak i zakrzepowo-zatorowego, mogą mieć także tło genetyczne, należy rozważyć jego ewentualną rolę również w przypadkach mikobakteriozy występującej w przebiegu nadciśnienia płucnego.

\section{Konflikt interesów}

Autorka nie zgłasza konfliktów interesów.

\section{Piśmiennictwo:}

1. Falkinham J.O. $3^{\text {rd }}$. Ecology of nontuberculous mycobacteria where do human infections come from? Semin. Respir. Crit. Care Med. 2013; 34: 95-102.

2. Griffith D.E., Aksamit T., Brown-Elliott B.A. i wsp. An official ATS/IDSA statement: diagnosis, treatment, and prevention of nontuberculous Mycobacterial diseases. Am. J. Respir. Crit. Care Med. 2007; 175: 376-416.

3. van Ingen J. Nontuberculous mycobacteria. W: Davies P.D.O., Gordon S.B., Davies G. (red.). Clinical tuberculosis. CRC Press, Boca Raton 2014; 419-430.

4. Daley C.L., Griffith D.E. Pulmonary nontuberculosis mycobacterial infections. Int. J. Tuberc. Lung. Dis. 2010; 14: 665-671.

5. Leung J.M., Olivier K.N. Nontuberculous mycobacteria: the changing epidemiology and treatment challenges in cystic fibrosis. Curr. Opin. Pulm. Med. 2013; 19: 662-669.

6. Aitken M.L., Limaye A., Pottinger P. i wsp. Respiratory outbreak of Mycobacterium abscessus subspecies massiliense in a lung transplant and cystic fibrosis center. Am. J. Respir. Crit. Care Med. 2012; 185: 231-232.

7. Bryant J.M., Grogono D.M., Greaves D. i wsp. Whole genome sequencing to identify transmission of Mycobacterium abscessus between patients with cystic fibrosis: a retrospective cohort study. Lancet 2013; 381: 1551-1560. 
8. van Ingen J. Diagnosis of nontuberculous mycobacterial infections. Semin. Respir. Crit. Care Med. 2013; 34: 103-109.

9. van Ingen J., Griffith D.E., Aksamit T.R., Wagner D. Pulmonary diseases caused by nontuberculous mycobacteria. Eur. Respir. Monogr., Tuberculosis, ERS, 2012; 58: 25-37.

10. Arena S.M., van Soolingen D., Ottenhoff T.H.M. Diagnosis and treatment of lung infection with non-tuberculous mycobacteria. Curr. Op. Pulm. Med. 2009; 15: 201-208.

11. Chan E.D., Iseman M.D. Underlying host risk factors for nontuberculous mycobacterial lung disease. Semin. Respir. Crit. Care Med. 2013; 34: 110-123.

12. Winthrop K.L., Yamashita S., Beekmann S.E. Mycobacterial and other serious infections in patients receiving anti-tumor necrosis factor and other newly approved biologic therapies: case finding through the emerging infection network. Clin. Infect. Dis. 2008; 46: 1738-1740.

13. Leung J.M., Olivier K.N. Nontuberculous mycobacteria in patients with cystic fibrosis. Semin. Respir. Crit. Care Med. 2013; 34: 124-134

14. Mai H.N., Hijikata M., Inoue Y. i wsp. Pulmonary Mycobacterium avium complex infection associated with the IVS8-T5 allele of the CFTR gene. Int. J. Tuberc. Lung Dis. 2007; 11: 808-813.

15. Colombo R.E., Hill S.C., Claypool R.J. i wsp. Familial clustering of pulmonary nontuberculous mycobacterial disease. Chest 2010; 137: 629-634.

16. Koh W.J., Kwon O.J., Kim E.J. i wsp. NRAMP1 gene polymorphism and susceptibility to nontuberculous mycobacterial lung diseases. Chest 2005; 128: 94-101.

17. Ryu Y.J., Kim E.J., Lee S.H. i wsp. Impaired expression of Tolllike receptor 2 in nontuberculous mycobacterial lung disease. Eur. Respir. J. 2007; 30: 736-742.

18. Fowler C.J., Olivier K.N., Leung J.M. i wsp. Abnormal nasal nitric oxide production, ciliary beat frequency and toll-like receptor response in pulmonary nontuberculous mycobacterial disease epithelium. Am. J. Respir. Crit. Care Med. 2013 187: 1374-1381.

19. Fritscher L.G., Marras T.K., Bradi A.C. i wsp. Nontuberculous mycobacterial infection as a cause of difficult-to-control asthma. Chest 2011; 139: 23-27.

20. Andrejak C., Nielsen R., Thomsen V.O. i wsp. Chronic respiratory disease, inhaled corticosteroids and risk of non-tuberculous mycobacteriosis. Thorax 2013; 68: 256-262.

21. Hojo M., Iikura M., Hirano S. i wsp. Increased risk of nontuberculous mycobacterial infection in asthmatic patients using long-term inhaled corticosteroid therapy. Respirology 2012; 17: 185-190.

22. Griffith D.E. Nontuberculous mycobacterial lung disease. Curr. Opin. Infect. Dis. 2010; 23: 185-190.

23. van Ingen J., Hoefsloot W., Dekhuijzen P.N.R. i wsp. The changing pattern of clinical Mycoibacterium avium isolation in the Netherlands. Int. J. Tuberc. Lung Dis. 2010; 14: 1176-1180.

24. Prevots D.R., Shaw P.A., Strickland D. i wsp. Nontuberculous mycobacterial lung disease prevalence at four Integrated Health Care Delivery Systems. Am. J. Respir. Crit. Care Med. 2010; 182: 970-976.

25. Kendall B.A., Winthrop K.L. Update on the epidemiology of pulmonary nontuberculous mycobacterial infections. Semin. Respir. Crit. Care Med. 2013; 34: 87-94.

26. Andrejak C., Thomsen V.O., Johansen I.S. i wsp. Nontuberculous pulmonary mycobacteriosis in Denmark. Am. J. Respir. Crit. Care Med. 2010; 181: 514-521.

27. Wyrostkiewicz D., Skorupa W., Jakubowska L. i wsp. Mikobakterioza u chorych na mukowiscydozę - opis trzech przypadków. Pneumonol. Alergol. Pol. 2014; 82: 561-567.

28. Wilińska E., Oniszh K., Augustynowicz-Kopeć E. i wsp. Mikobakterioza płuc u chorych na nadciśnienie płucne zakrzepowo-zatorowe i idiopatyczne tętnicze nadciśnienie płucne. Pneumonol. Alergol. Pol. 2014; 82: 495-502. 